\title{
The Compounding Effect of Investors' Cognition and Risk Absorption Potential on Enhancing the Level of Interest towards Investment in the Domestic Capital Market
}

\author{
Yadav Devi Prasad Behera ${ }^{1} \mathbb{D}$, Sudhansu Sekhar Nanda ${ }^{2, *}$, Saroj Kumar Sahoo ${ }^{1, *}$ and Tushar Ranjan Sahoo ${ }^{1}$ \\ 1 P.G. Department of Business Administration, Sambalpur University, Burla, Sambalpur 768019, Odisha, India; \\ deviprasadyadav2009@gmail.com (Y.D.P.B.); sahoo.tushar571@gmail.com (T.R.S.) \\ 2 Department of Finance, ASBM University, Bhubaneswar 754012, Odisha, India \\ * Correspondence: nandasudhansusekhar.87@gmail.com (S.S.N.); sahoosaroj78@gmail.com (S.K.S.); \\ Tel.: +91-9439299659 (S.S.N.); +91-9437111277 (S.K.S.)
}

Citation: Behera, Yadav Devi Prasad Sudhansu Sekhar Nanda, Saroj Kumar Sahoo, and Tushar Ranjan Sahoo. 2021. The Compounding Effect of Investors' Cognition and Risk Absorption Potential on Enhancing the Level of Interest towards Investment in the Domestic Capital Market. Journal of Risk and Financial Management 14: 95. https://doi.org/10.3390/jrfm14030095

Academic Editor: Michael McAleer

Received: 4 December 2020

Accepted: 24 January 2021

Published: 28 February 2021

Publisher's Note: MDPI stays neutral with regard to jurisdictional claims in published maps and institutional affiliations.

Copyright: (c) 2021 by the authors. Licensee MDPI, Basel, Switzerland. This article is an open access article distributed under the terms and conditions of the Creative Commons Attribution (CC BY) license (https:// creativecommons.org/licenses/by/ $4.0 /)$.

\begin{abstract}
It is eminent to understand, be aware of and encourage domestic retail investors towards investment in the capital market in a developing economy such as India for tackling the situation of capital insufficiency and financial instability. Therefore, the study was purposed to find out the different dimensions of cognition that affect investment attitude and the different characteristics of risk absorption affecting the investment decision making. The study also intended to find the direct and the mediating impact of investors' cognition directly and through risk-absorption scenarios on the level of interest on investment. The study used the causative research design and by using stratified random sampling, received 392 responses from investors with risk-absorption characteristics from four strata of Odisha (a state of India) through a self-constructed questionnaire. Factor analysis was used to find out the factor of cognition and risk absorption. Multiple linear regression was used to find out the effect of both factors of cognition and risk absorption on the intensity of purchase financial product or level of interest in investment. Mediation analysis was used to find the mediating impact showing the direct and indirect impact of cognition on interest in investment and through the factors risk absorption. The study found that the dimensions of cognition (hot, cold, social and meta) have a significant impact on the level of interest towards investment, so financial product sellers must use these dimensions and sources of cognition to bring up interest from the domestic investor to invest in the domestic capital market. It has also been found that the risk-absorption characteristics play a mediating and vital role in the relation between investors' cognition and level of interest in investment. Therefore, it is imperative to uplift the risk-absorption capacity through different dimensions of cognition and sources of information, which can reflect in a better understanding of the market and investment scenarios.
\end{abstract}

Keywords: investment attitude; decision making; financial products; behavioural finance and risk tolerance

\section{Introduction}

Many developing nations such as India, Brazil, Argentina, Indonesia and many south east Asian countries are vulnerable to external economic crisis due to over dependency on foreign soil for their capital need (De 2020). It has been seen that, when the major economies in the world trembles, the nations depending on the major economies start shattering. The world crisis has affected the major developing nations and its growing economy. Due to openness in the economy, India's economy is susceptible to world economic crises. The Latin American debt crisis in 2002, the great depression in 2007 and the European crisis in 2010 have shown the devastating impact of world crises on the Indian economy. (Srinivas 2011). The world has also seen many financial crises arising out of pandemicsandepidemics such as SARS, swine flu, H1N1 virus, COVID-19, etc. (Bluedorn et al. 2020; Peckham 
2013). These world financial crises have negative effectsin the short term, and in some cases, this can extend to long-term unconstructive consequences (Merle 2018). The financial crises in the globalised era are not just limited to the extent of the country of origin but also affect many countries connected with international support systems and international trade. The crises in one country lead to the crises with other dependent nations. Many a time, the Indian economy has shaken due to the devastation that happened in connected countries'trade and business. The fall of the economy in one country leads to withdrawal of capital provided by that country in the form of foreign direct investment (FDI) and foreign portfolio investment (FPI). Just not India but many developing nations in the subcontinent region and the south east Asian region are affected by the withdrawal of FDI and FPI due to world economic crises, in spite of having good domestic parameters (Caycedo 2018).

India's liberal foreign direct investment (FDI) and foreign portfolio investment (FPI) policies, similar to many other developing economies, have been proved as a gain for the economic growth for many years, but it has also made the Indian economy penetrable to external unforeseen situations. In recent years, big world economic crises such as the great crisis of the United States of America in 2008 (Razack and Thimmaiah 2014), the Japan crisis in 2011 (Lakshman 2011), the Euro debt crisis in 2011-2012 (Mukherjee 2012) and the COVID-19 crisis in 2020 (Ramakrishnan 2020) have shown the negative facet of open economic policies. Even if the fundamentals of the Indian economy were strong in some of these situations, the impact of global crises made it fall. Therefore, we need to be capital adequate from the domestic resources especially through domestic retail investors.

The participation of Indian domestic retailer investors, such as many other developing nations, is very discouraging for their domestic economy (IBRD 2017). The contribution towards investment is less than $3 \%$ in India, which seems insignificant as compared to the United States of America (55\%) (Agrawal 2020). Only 40.8 million people in India have a dematerialisation of share (DEMAT) account in a population of more than 1.36 billion (Sultana 2020). The Indian investors, investing in mutual funds and systematic investment plans relating to the equity market, hold up to only 2.37 and $85 \%$ of the total investors in mutual funds coming from top 30 cities of India, which shows that India's financial system is just concentrating on the major cities and has failed significantly to significantly draw the attention of rural retail investors (Nair 2020). The above statistics show how India's financial intermediaries failed to encourage and understand the behaviour of Indian investors.

Domestic investments from domestic investors or the retail investors are very much important for filling the capital and financial need of any nation by utilising the disposable income from the public and depending less on the external financing from other countries. Bakari (2017) stated that domestic investments are very important for the economic development of any nation. Bal et al. (2016) also supported the fact that domestic investment lead to the growth of GDP, as it promotes capital formation. The increase in capital formation through the disposable income from domestic investment could be pathway for economic investment, and for this purpose, we need to encourage domestic investors (Pegkas and Tsamadias 2016). Therefore, to encourage more and more domestic-based investment, we need to encourage the domestic individual investors. So, it has been essential to study the characteristics of domestic investors and their intention to invest.

Investments are subjected to a knowledge-driven scenario. Brain processing through various forces is needed for understanding, imitating and investing in different investment platforms. Therefore, the different sources by which the mental processing could be done are needed to be studied for a better understanding of the investment mechanisms of the investors. The investment dynamics are also driven by the risk-tolerance character of the investors. On stimulating the risk-taking potential, we can aggravate the investors to go for purchasing the investment. Therefore, we also need to study the factors affecting the risk-taking potential of the investors along with knowing their present risk-taking ability. Therefore, this paper has been focused to find out the different dimension of cognitions, which can help to build decision-making potential for investment in the domestic capital 
market as different dimensions of cognition are different potential sources to drive one's attitude and intent. Along with cognition, this study also concentrated on finding out different traits that can be inculcated in the investors, so that they can take firmand better financial product investment decisions.

\subsection{Literature Review}

Human psychology plays an important part in the everyday life of human beings in taking various decisions of life. Investment being a matter of necessity in today's lifestyle, there is a concern about an investor's psychology with regard to what drives him for investment. Investors' informative view point and the processing of information help make the investment decision and develop the risk-taking capacities. Therefore, in this literature review, we have concentrated on the cognitive factors relating to an investor's psychology and the risk-bearing capabilities of the investors.

\subsubsection{Risk-Taking Abilities}

Risk-taking capabilities have been a major aspect when it comes to investing your hard-earned money in the scenario of return uncertainties. Risk-taking aptitude is different from investor to investor. Generally, the investors are categorised into three on the basis of their risk-taking abilities (Harris and Wu 2014). They can be risk averse, risk neutral and risk seeking. The risk averse investors always ceases to take any risk and avoid risk to the maximum extent. The risk neutral investors are basically those investors who intend to take limited risk in the investment and do not extend their current investment to a greater number of years. The risk seekers are the investorswhoaim to obtain more return out of a risky investment and continue to do so for a more extended time (Dev 2014). Financial risk tolerance is the maximum amount of risk or uncertainty that someone is willing to bear or accept, while making a financial decision, considering the economic and social factors relating an individual (Grable 2000). Risk tolerance is measured by five factors such as traditional risk factor, reflective risk factor, allocation risk factor, capacity risk factor and knowledge risk factor.

This ability of taking risk and risk averse thoughts creates a likelihood towards investment or creates resiliency in the mind of the investors to make an investment decision (Feldman and Lepori 2016). On the other hand, Dickason and Ferreira (2018) have found that the perceived environmental security relating risky investment affects their decision-making process and the behaviour of risk aversion comes into play. Saurabh and Nandan (2018) supported his arguments and stated that the financial risk attitude affects the financial satisfaction or else leads to dissatisfaction towards an investment. Broihanne et al. (2014) also found that the risk perception and the risk-taking behaviour amplify or reduce the tenacity of investment decision.

\section{Factors Affecting Risk Tolerance}

There are many elements affecting the risk-tolerance behaviour of the investors and their risk-bearing capacity. These factors are the emotional intelligence and locus of control, which have a positive effect on financial risk taking. Aydemir and Aren (2017) also stated the fact that the emotional intellect among the investor is the major factor behind the risk-tolerance conduct of the individual. Sweet (2013) explained that income and education have an individual impact and effect in combination. Anderson (2016) also showed that factors such as family profile and financial literacy impact financial risk at the individual level. Mohan and Singh (2017) supported the information that financial risk tolerance enhances with an increase in the level of education of investors. Anbar and Eker (2010) and Chattopadhyay and Dasgupta (2015) have shown from their studies that married persons are more risk unenthusiastic than unmarried persons. Risk-tolerance capacity fluctuates from male and female and personality of conscientiousness (Wong and Carducci 2013). To support his arguments, Saurabh and Nandan (2018) assert that the internal consistencies and satisfactory reliabilities are able to construct and enhance the risk handling and increase 
risk-tolerance level. Reddy and Mahapatra (2017) explained from their study that personal fiscal knowledge and the demographic variables such as age and educational level affects the risk-tolerance level. Wasiuzzaman and Edalat (2016) found from his learning that social network use can convey the information and relevant data concerned with the investment, which will increase the risk-tolerance level.

Effect of Risk-Absorption Capacity (RA) on Level/Degree of Interest in Investment (LII)

Risk and return have two equivalent aspects of investment theory. The higherrisk investment would result in more return. The risk-tolerance ability has been the important constraint behind the investment decision. Khan (2017) found that people with more financial risk-tolerance behaviour possess more interest in investment. Corter and Chen (2006) explain from their study that the investor with the larger risk-handling capability emerges to be the most enthusiastic for investment. Risk-absorption capacity (RA) reflects the risk-tolerance nature of the investors; those who are investing for a greater duration of time, repeating such an investment, suggesting investment plans with others and waiting for the market to rise rather than selling in the falling market. This risk-absorption capacity induces the investor to take calculative and more risk in investments. Supporting the finding Kannadhasan (2015) also found that the investor with the greater risk-tolerance behaviour is likely to invest more in risky assets. Risk perception holdsa lot of sway in the investment decision (Sindhu and Kumar 2014). The risk associated with investment frequently makes the investor use their cognitive ability to make the decision (Shafi and Fatima 2016).

\subsubsection{Cognition}

Being one of the constituents among the tri-component of attitude formation, cognition has taken a prior component in developing purchase attitudes towards investment among the investor. Investment is a subject matter of examination and understanding, so cognition plays a vital role. Starting from resolving the matter of investors to a confirmed investment decision, cognition is the distinguished focus objective. It provides a better psychological processing environment for understanding relating to the financial product, which ultimately helps the investors to make an improved investment decision. The cognition is non-emotional, emotional and social. The different magnitude of cognition affects the attitude of investors in the direction of investment individually, and also, the combined effect brings a greater positivity towards investment. Niznikiewicz (2013) explained that the dimensions of cognition can be cold cognition (non-emotional), hot cognition (emotional), social cognition (current social environment) and meta cognition (learning process).

\subsubsection{Cold Cognition (CC)}

Cognition is the mental process involving gaining knowledge through thinking knowing, remembering, reviewing and problem solving (Cherry 2019). This knowing process could engage emotional sources of information and can be non-emotional as well. Cold cognition involves the mental process in which memories, working memory, attention level, sensory processing, phonology and the non-emotional semantics play a key role by which a person acquires knowledge about a particular subject (Sahakian 2017). Further (Bhushan 2014; Dhingra et al. 2017), the information relating to investment guidesthe investors' awareness through continuous and conscious education, which helps in decision making. In addition of the above facts, (Mane 2016; Saravana kumar et al. 2011) we must also give weight to the news and awareness about liquidity, diversification and the fine-framed regulation relating to investment scenarios, which ultimately have an impact on their decision. An investor uses their intelligence to evaluate the current and past performance of the investment (Jagongo and Mutswenje 2014). The analysis of macro-economic factors and risk and return factors affect the investment propensity (Shinde and Zanvar 2014). 


\subsubsection{Hot Cognition (HC)}

Investors, being social animals, are influenced by their emotional surroundings. Their activities and decisions reflect the emotional behaviour around them. "Hot cognition" is said to be the emotional way of psychological processing. It is developed through emotional processing, emotional semantics, emotional prosody, conversing intentions of self and understanding emotions and empathy (Niznikiewicz 2013). Many investors pursue information or follow the knowledge of related people or sources with whom they are emotionally associated. Blackwell et al. (2011) and Cabosky (2016) established from their study that hot cognition is the emotional-based cognition through emotional resilience, and social interaction influences the speed and accuracy of the decision of the people. Redlawsk (2002) holds the facts and concluded that hot cognition conveys an emotional belongingness in decision making and affects the degree of potency of the decision. Emotional affection is from the family and peer group, which influences their purchasing intention (Kshetri and Jha 2016; Massa 2003).

\subsubsection{Social Cognition (SC)}

Social cognition is the mental process by which one person perceives, thinks and attends to another person in our social world (Cherry 2019; Currás-Pérez et al. 2013). Social cognition controls social interaction, and social interaction helps a person or affects decision making. Fiske (1993) and Yuksel et al. (2016) found that society or an acquaintance can guide investors to a general agreement or consensus. This shows that the known information and known people leads to social cognition, which helps to seize a relatively confirmatory decision. Two studies (Ferreira et al. 2014; Ickes et al. 1990) also added that if the intensity of colleague and social cognition is raised (Sahoo et al. 2020), then the degree of acceptability of the theory of those within the social environment will be more (Bounkhong 2017; He et al. 2015). Social media are the platform for information creation and circulation regarding investment patterns (Islamoğlu et al. 2015; Pang and Lee 2008). Facebook, Twitter, etc., havebeen efficient in the buying decisions among different age groups especially in millennials (Boateng and Okoe 2015; Duffett 2015). Often social media creates brand awareness, which ultimately helps in purchasing decisions (Bruhn et al. 2012; Cocosila and Igonor 2015).

\subsubsection{Meta Cognition (MC)}

Meta cognition is the intellectual process originates from the person's own learning. It develops the learning from their own thoughts. It starts with its own desire to find out and evaluate the strengths and weaknesses, preparing the strategies and learning from the action (Spencer 2018). It is cognition developed through self-directed goals and experience. Meta cognition shapes the future-oriented decision that was previously experienced. (Bennet et al. 2012; Lee et al. 2012) stated that the person, experience or selfanalysed learning and cognition assist them in analysing prospective situations and change their attitude to make a better decision. Guo (2012) and Sukanya and Thimmarayappa (2015) also found that the learners' independent awareness of the mental processing ability to reflect, assess its actions and control its own cognitive process helps to make good strategies and could lead to a better decision.

Effect of Investors' Cognition (IC) on Level/Degree of Interest in Investment (LII)

Pothos and Busemeyer (2013) concluded from their study that the various dimensions of cognition become the rationality in decision making. The relevance of cognition and cognitive abilities will create a positive intention to invest. Yang (2015) explains that cognition or cognitive ability helps to change the dynamism of strategies and helps to implement the strategic transform. It leads to a change in the propensity of decision making and helps to make confirmed decisions. Tidwell et al. (2000) explained that there is necessitate for cognition in every decision made. The strength and weakness of the decision rely upon the relevance of cognition in a particular field. The different types of 
cognition support an individual to take a firmed purchase decision (Akhter and Ahmed 2013; Kim 2012).

\subsection{Problem Statement}

Human decisions relating to the purchase of any product depends on the psychological characteristics, which can be driven by many components such as the cognitive, conative and the affective components (Wengrzyn 2013). However, the financial product is just like any other necessity product for the investors, which are determined by the psychological characteristics and attitude of the investor, but this character and attitude are mostly influenced by the mental processing or the cognitive element. As investments are subjected to risk of loss, the risk-taking ability of the investors also plays a major role in the purchase decision of the financial products. Cognition affects both the level of interest in the investors towards investment as well as developing the qualities of the investor having risk absorption. The development of this risk-absorption quality again leads to changes in the level of interest in investment. In this regard, the research question is "can risk-absorption potential among investors play a mediating role in the impact relationship of investors' cognition on the level of interest in investment?"

\subsection{Objective of the Study}

1. To find the different dimension of investors' cognition.

2. To explore different characteristics of the investor having risk absorption.

3. To analyse the direct impact of the dimension of investors' cognition on the level of interest in investment.

4. To study the mediating effect of risk-absorption factors on the relationship between the investors' cognition and the level of interest in investment.

\subsection{Hypothesis of the Study}

Hypothesis 1 (H1). There is a significant direct impact of the dimension of investors' cognition on the level of interest in investment.

Hypothesis 2 (H2). There is a significant mediating effect of risk-absorption factors on the relationship between the investors' cognition and the level of interest in investment.

\subsection{Scope of the Study}

The is based on knowing the cognition effect on both risk-tolerance capacity of the investors as well as helping in enhancing investors' interest level towards financial products such as systematic investment plans (SIP) and mutual funds linked with the stock market. It can help the managers of a broking firm as well as asset management companies to set specific targets for investors and can form suitable strategies to develop their risk-taking ability and can also help in developing their information processing abilities relating to investment. A better informative possessed client is always been a long-term asset for these companies, as they tend to invest for a longer duration of time without panicking because of market fluctuation.

\section{Materials and Methods}

\subsection{Research Design}

The study followed the causal research design to find out the impact of investors' cognition on level of interest in investments by investors. Population for the study are the investor having risk absorption of SIP and mutual fund having four qualities in common. Those are that who invest in risk category of investment, wait for falling market to rise again, invest repetitively and for longer periods and suggest the same financial products to others. The population size is infinite. In order to determine the minimum sample size, 
Cochran's formula (Cochran 1963) was used as stated below; when the population size is infinite.

$$
\mathrm{n}_{0}=\frac{\mathrm{z}^{2} \mathrm{pq}}{\mathrm{e}^{2}}
$$

where, " $\mathrm{n}_{0}$ " is the sample size, " $\mathrm{z}$ " is the selected critical value of desired confidence level, " $\mathrm{p}$ " is the estimated proportion of characteristics present in the population, and $q$ is $1-\mathrm{p}$ and $\mathrm{e}$ is the level of precision. For a large population, the degree of variability is not known, so " $\mathrm{p}$ " can be assumed to be 0.05 , and " $\mathrm{q}$ " is 0.05 . Confidence level is assumed to be $95 \%$, and significance level is $5 \%$, " $\mathrm{z}$ " value assumed to be 1.96 . Therefore, calculating the formula, we can obtain " $\mathrm{n}_{0}$ " as 384 . Stratified random sampling technique is used to collect the sample from four strata of Odisha state, India, based on the geographical segmentation, which are northern Odisha, southern Odisha, eastern Odisha and western Odisha. A total of 392 sample size from 4 different stratums were included for data collection. A structure questionnaire with a five-point Likert scale is administered for data collection. The data collected are from between the March-September 2020. The scale for the question ranges between "completely agree" to "very little agree". The scale reliability (of the questionnaire) is measured by Cronbach's alpha. The data adequacy is tested through KMO (Kaiser-Meyer-Olkin Measure of Sampling Adequacy) statistics. The factors analysis is used to extract the dimension of the investors' cognition and the characteristics reflecting investor having risk absorption. The statistical technique, multiple linear regression, is used to find out the impact of the dimension of investors' cognition and risk-absorption characteristics on the level of interest in investment. Process macro 3.5 is used to find out the mediating effect of risk-absorption factors on the relationship between the investors' cognition and the level of interest in investment. The data analysis is done through SPSS 23.0. The literatures are studied from the database of Elsevier (SCOPUS indexed), Emerald Insight, SAGE, Google scholar and UGC care journals.

\subsection{Respondent Profile}

Out of the total respondents, $65.1 \%$ are male and $34.1 \%$ are female. The majority of responses are from age group of 21-25 (15.1\%), 26-30 (24.2\%), 31-35 (26.3\%), 36-40 (16.3\%) and rest from other age groups. Thirty-eight percent and $62 \%$ of the total respondents are single and married, respectively. Widely held respondents are with PG (post graduation)level education (50.8) and another professional degree (38.5\%). Government officials make up $35.2 \%, 23 \%$ are private sector employees and the rest belongs to other groups. Of total respondents, 9.4\% earn incomes more than Rs 100,001, 12\% come from the income group of $80,001-100,000,17 \%$ from $60,001-80,000$ and the rest from other groups. The majority of people (50.3\%) invest less than 5000, and 32.7\% people invest between $5001-10,000$ per month in SIP and mutual funds.

\section{Results}

\subsection{Scale Statistics and Scale Reliability}

The scale (questionnaire) is optimally reliable, i.e., $81 \%$, as the standardised Cronbach's alpha is 0.810 with 36 items in the structured questionnaire (including seven demographic variables), referred from Table 1.

Table 1. Scale and Reliability Statistics.

\begin{tabular}{ccccccc}
\hline & \multicolumn{2}{c}{ Scale Statistics } & \multicolumn{3}{c}{ Reliability Statistics } \\
\hline Mean & Variance & $\begin{array}{c}\text { Std. } \\
\text { Deviation }\end{array}$ & $\begin{array}{c}\text { N of } \\
\text { Items }\end{array}$ & $\begin{array}{c}\text { Cronbach's } \\
\text { Alpha }\end{array}$ & $\begin{array}{c}\text { Cronbach's Alpha } \\
\text { Based on } \\
\text { Standardized Items }\end{array}$ & $\begin{array}{c}\text { N of } \\
\text { Items }\end{array}$ \\
\hline 200.29 & 211.711 & 14.550 & 55 & 0.804 & 0.810 & 55 \\
\hline
\end{tabular}




\subsection{Factor Analysis for Finding the Dimensions of Investor Cognition}

KMO measure of sample adequacy is $72 \%$, which is significant $(0.000)$, so explorative factor analysis is applicable here. The significant (0.000) value (0.717) of Bartlett's test of sphericity justifies that the correlation matrix is not an identity matrix. This shows that the sample is appropriate and can produce distinct factors as shown in Table 2.

Table 2. Sample Adequacy.

\begin{tabular}{ccc}
\hline \multicolumn{3}{c}{ KMO (Kaiser-Meyer-Olkin Measure of Sampling Adequacy) and Bartlett's Test } \\
\hline \multicolumn{2}{c}{ Kaiser-Meyer-Olkin Measure of Sampling Adequacy } & $\mathbf{0 . 7 1 7}$ \\
\hline \multirow{3}{*}{ Bartlett's Test of Sphericity } & Approx. Chi-Square & 963.364 \\
\cline { 2 - 3 } & df & 105 \\
\cline { 2 - 3 } & Sig. & 0.000 \\
\hline
\end{tabular}

With Varimax rotation and Kaiser normalization, five factors are extracted as described in the rotated component matrix, which are named as hot cognition, social cognition, cold cognition, meta cognition and past investment success; these are the different dimensions of cognition as shown in Table 3.

Table 3. Rotated Component Matrix.

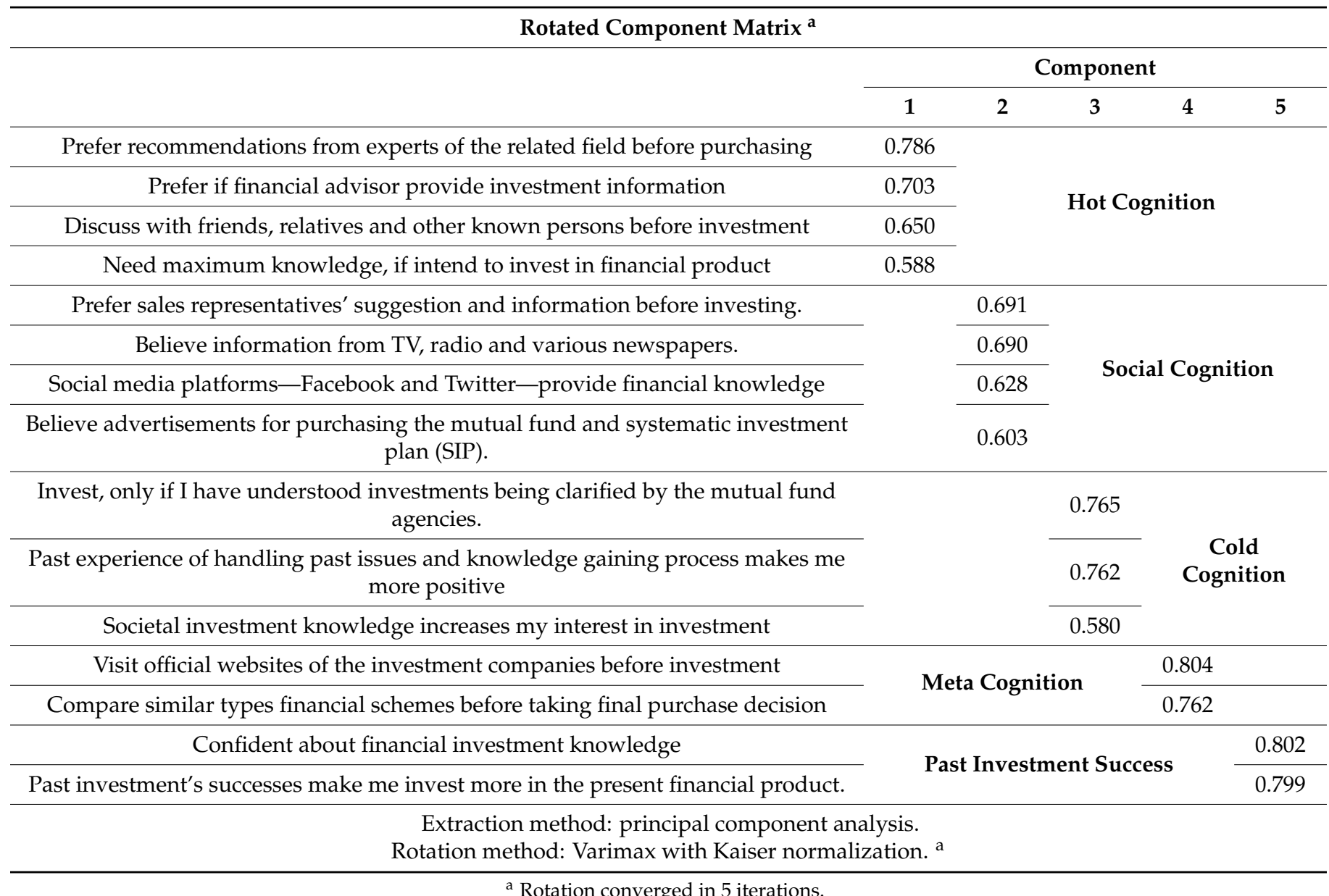

\footnotetext{
${ }^{a}$ Rotation converged in 5 iterations.
} 


\subsection{Factor Analysis of Risk Absorption}

KMO measure of sample adequacy is $72 \%$, which is significant $(0.000)$, so explorative factor analysis is applicable here. The significant $(0.000)$ value (0.716) of Bartlett's test of sphericity justifies that the correlation matrix is not an identity matrix. This shows that the sample is appropriate and can produce distinct factors as shown in Table 4.

Table 4. Sample Adequacy.

\begin{tabular}{lcc}
\hline \multicolumn{2}{c}{ KMO and Bartlett's Test } \\
\hline \multirow{2}{*}{ Kaiser-Meyer-Olkin Measure of Sampling Adequacy } & $\mathbf{0 . 7 1 6}{ }^{\text {* }}$ \\
\hline \multirow{3}{*}{ Bartlett's Test of Sphericity } & Approx. Chi-Square & 1180.836 \\
\cline { 2 - 3 } & df & 153 \\
\cline { 2 - 3 } & Sig. & $\mathbf{0 . 0 0 0}$ \\
\hline
\end{tabular}

With Varimax rotation and Kaiser normalization, six factors are extracted as described in the rotated component matrix, which are named as risk-seeking attitude, strategic investment planner, recurrence of investment, risk tolerance and protracted investment behaviour are the different characteristics of investor having risk absorption as shown in Table 5.

Table 5. Rotated Component Matrix.

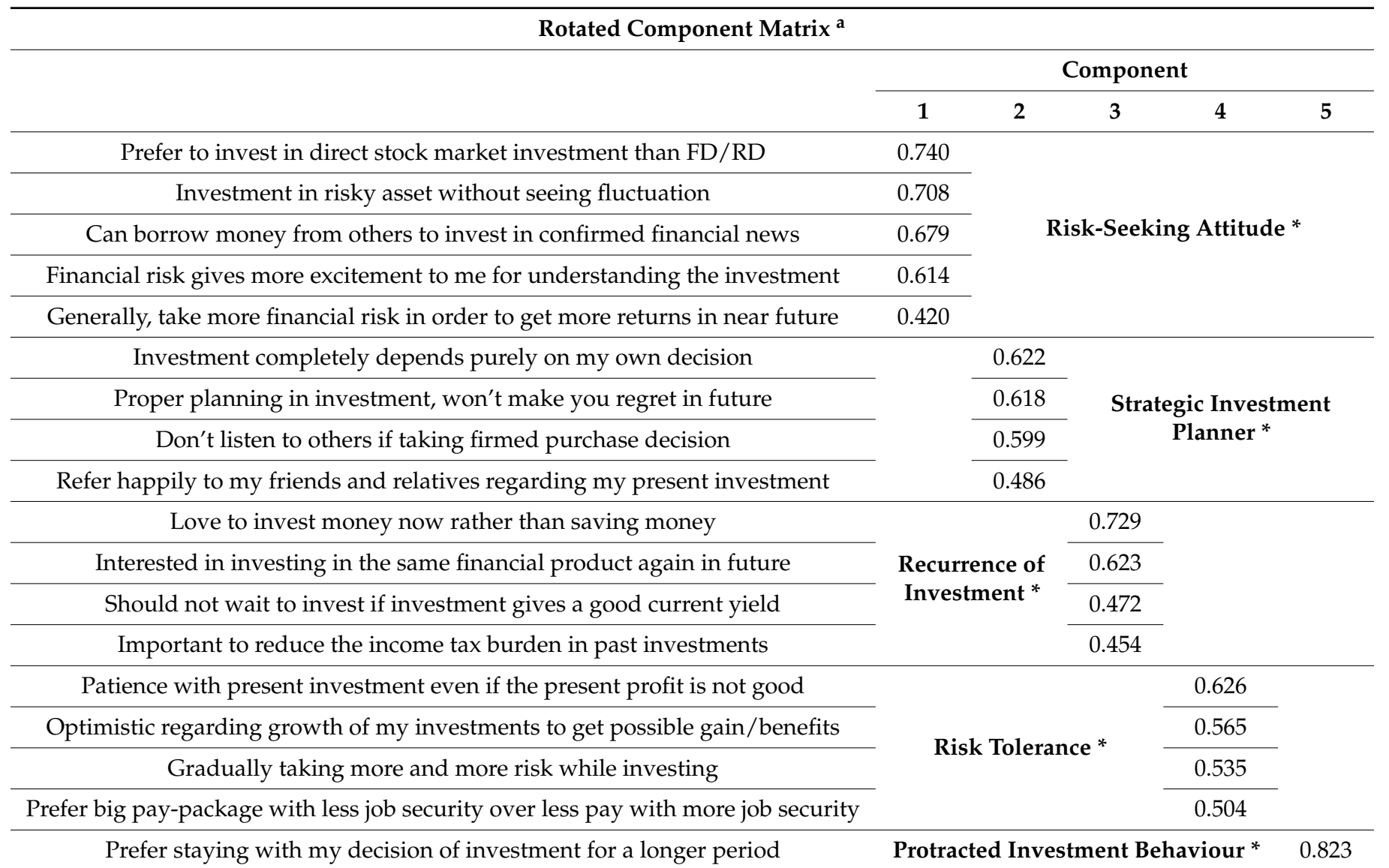


3.4. Multiple Linear Regression to Show the Impact of the Dimension of Cognition and the Factors Risk-Absorption Behaviour on the Level of Interest in Investment

Table 6, the ANOVA results, shows that the " $\mathrm{F}$ " statistic (61.596) is significant $(p=0.000)$, which is within the range of 0.050 . Therefore, it can be inferred that the regression analysis is fit for the above purpose.

Table 6. ANOVA.

\begin{tabular}{|c|c|c|c|c|c|c|}
\hline \multicolumn{7}{|c|}{ ANOVA $^{a}$} \\
\hline & Model & Sum of Squares & df & Mean Square & $\mathbf{F}$ & Sig. \\
\hline \multirow{3}{*}{1} & Regression & 85.519 & 10 & 8.552 & $61.596 *$ & $0.000^{b}$ \\
\hline & Residual & 52.897 & 381 & 0.139 & & \\
\hline & Total & 138.416 & 392 & & & \\
\hline
\end{tabular}

a Dependent variable: level of interest in investment; ${ }^{\mathrm{b}}$ predictors: (constant), protracted investment behaviour risk tolerance, recurrence of investment, strategic investment planner, risk seeking attitude, meta cognition, past investment success, cold cognition, social cognition, hot cognition.

Table 7 shows that the dimensions of investors' cognition and the behaviour of investorscarrying out risk absorption have an effect of approx.61\% on the level of interest in investment by the investors as the adjusted $\mathrm{R}^{2}$ is 0.608 , and it is significant $(p=0.000)$, which is within the range of 0.050 . The variables are independent of each other, as the variables show no auto co-relation symptoms. It is justified from the Durbin-Watson statistics (should vary from 1.5 to 2.5 ). In current research, it is 1.831 that justifies the above argument.

Table 7. Model Summary.

\begin{tabular}{|c|c|c|c|c|c|c|c|c|c|c|}
\hline \multicolumn{11}{|c|}{ Model Summary ${ }^{b}$} \\
\hline \multirow[b]{2}{*}{ Model } & \multirow[b]{2}{*}{$\mathbf{R}$} & \multirow{2}{*}{$\begin{array}{c}\mathbf{R} \\
\text { Square }\end{array}$} & \multirow{2}{*}{$\begin{array}{l}\text { Adjusted } \\
\text { R Square }\end{array}$} & \multirow{2}{*}{$\begin{array}{l}\text { Std. Error } \\
\text { of the } \\
\text { Estimate }\end{array}$} & \multicolumn{5}{|c|}{ Change Statistics } & \multirow{2}{*}{$\begin{array}{l}\text { Durbin- } \\
\text { Watson }\end{array}$} \\
\hline & & & & & $\begin{array}{l}\text { R Square } \\
\text { Change }\end{array}$ & $\begin{array}{c}F \\
\text { Change }\end{array}$ & df1 & df2 & $\begin{array}{l}\text { Sig. F } \\
\text { Change }\end{array}$ & \\
\hline 1 & $0.786^{\mathrm{a}}$ & 0.618 & 0.608 * & 0.37261 & 0.618 & 61.596 & 10 & 381 & 0.000 & 1.831 \\
\hline
\end{tabular}

a Predictors: (constant), protracted investment behaviour, risk tolerance, recurrence of investment, strategic investment planner, risk seeking attitude, meta cognition, past investment success, cold cognition, social cognition, hot cognition; ${ }^{b}$ dependent variable: level of interest in investment.

Out of the 10 factors (five dimensions of investors' cognition and five traits of investors carrying out risk absorption), the most important factors that significantly enhance the level or degree of interest in investment are cold cognition, meta cognition, risk seeking attitude, strategic investment planner, recurrence of investment, risk tolerance, protracted investment behaviour with significance $(0.000,0.012,0.003,0.000,0.000,0.000$ and 0.000$)$ ), which is within the range of 0.050 . The beta values are $0.189,0.0089,0.117,0.159,0.587$, 0.252 and 0.124 , respectively, as shown in Table 8. The VIF (Variance Inflation Factor) values are less than 2.00 in every case, and one factor possesses tolerance values as 0.645 ; the rest of the factors possess more than 0.7 tolerance values, which shows that multicollinearity does not exist in the above regression.

From the above results, a regression model is formulated as follows:

$Y($ LII $)=3.702+0.189$ (Cold Cognition) +0.089 (Meta Cognition $)+$

0.117 (Risk Seeking Attitude) + 0.159 (Strategic Investment Planner) + 0.587 (Recurrence of Investment) +0.252 (Risk Tolerance) +0.124 (Protracted Investment Behaviour) + E 
Table 8. Coefficients.

\begin{tabular}{|c|c|c|c|c|c|c|c|c|c|c|c|}
\hline \multicolumn{12}{|c|}{ Coefficients $^{a}$} \\
\hline & \multirow{2}{*}{ Model } & \multicolumn{2}{|c|}{$\begin{array}{l}\text { Unstandardized } \\
\text { Coefficients }\end{array}$} & \multirow{2}{*}{$\begin{array}{c}\begin{array}{c}\text { Standardized } \\
\text { Coefficients }\end{array} \\
\text { Beta } *\end{array}$} & \multirow{2}{*}{$\mathbf{t}$} & \multirow{2}{*}{ Sig. * } & \multicolumn{3}{|c|}{ Correlations } & \multicolumn{2}{|c|}{$\begin{array}{l}\text { Collinearity } \\
\text { Statistics }\end{array}$} \\
\hline & & B & $\begin{array}{l}\text { Std. } \\
\text { Error }\end{array}$ & & & & $\begin{array}{l}\text { Zero- } \\
\text { order }\end{array}$ & Partial & Part & Tolerance & VIF \\
\hline \multirow{11}{*}{1} & (Constant) & 3.702 & 0.019 & & 196.719 & 0.000 & & & & & \\
\hline & Hot Cognition & -0.031 & 0.022 & -0.052 & -1.406 & 0.161 & 0.066 & -0.072 & -0.045 & 0.726 & 1.378 \\
\hline & Social Cognition & -0.036 & 0.022 & -0.061 & -1.644 & 0.101 & 0.141 & -0.084 & -0.052 & 0.734 & 1.362 \\
\hline & Cold Cognition & 0.113 & 0.022 & $0.189 *$ & 5.234 & $0.000 *$ & 0.485 & 0.259 & 0.166 & 0.767 & 1.304 \\
\hline & Meta Cognition & 0.053 & 0.021 & $0.089 *$ & 2.513 & $0.012 *$ & 0.198 & 0.128 & 0.080 & 0.808 & 1.237 \\
\hline & $\begin{array}{c}\text { Past Investment } \\
\text { Success }\end{array}$ & 0.039 & 0.021 & 0.066 & 1.885 & 0.060 & 0.113 & 0.096 & 0.060 & 0.826 & 1.211 \\
\hline & $\begin{array}{c}\text { Risk-Seeking } \\
\text { Attitude }\end{array}$ & 0.070 & 0.023 & $0.117 *$ & 2.964 & $0.003 *$ & 0.126 & 0.150 & 0.094 & 0.645 & 1.550 \\
\hline & $\begin{array}{c}\text { Strategic } \\
\text { Investment } \\
\text { Planner }\end{array}$ & 0.095 & 0.022 & $0.159 *$ & 4.348 & $0.000 *$ & 0.222 & 0.217 & 0.138 & 0.745 & 1.342 \\
\hline & $\begin{array}{l}\text { Recurrence of } \\
\text { Investment }\end{array}$ & 0.349 & 0.021 & $0.587 *$ & 16.293 & $0.000 *$ & 0.641 & 0.641 & 0.516 & 0.772 & 1.295 \\
\hline & Risk Tolerance & 0.150 & 0.020 & $0.252 *$ & 7.448 & $0.000 *$ & 0.267 & 0.356 & 0.236 & 0.875 & 1.143 \\
\hline & $\begin{array}{l}\text { Protracted } \\
\text { Investment } \\
\text { Behaviour }\end{array}$ & 0.074 & 0.020 & $0.124 *$ & 3.621 & $0.000 *$ & 0.156 & 0.182 & 0.115 & 0.860 & 1.162 \\
\hline
\end{tabular}

${ }^{\text {a }}$ Dependent variable: level of interest in investment.

3.5. Multiple Linear Regression to Show the Impact of Moderating and Mediating Variables on the Dependent Variable through Process Macro 3.5

In order to show the mediation effect of the risk absorption (RA) in the relationship between the investors' cognition (IC) and the level of interest in investment (LII), Process 3.5 is used. Model no. 4 is used to show the statistical and conceptual Figure 1 for the relation (Hayes 2013).
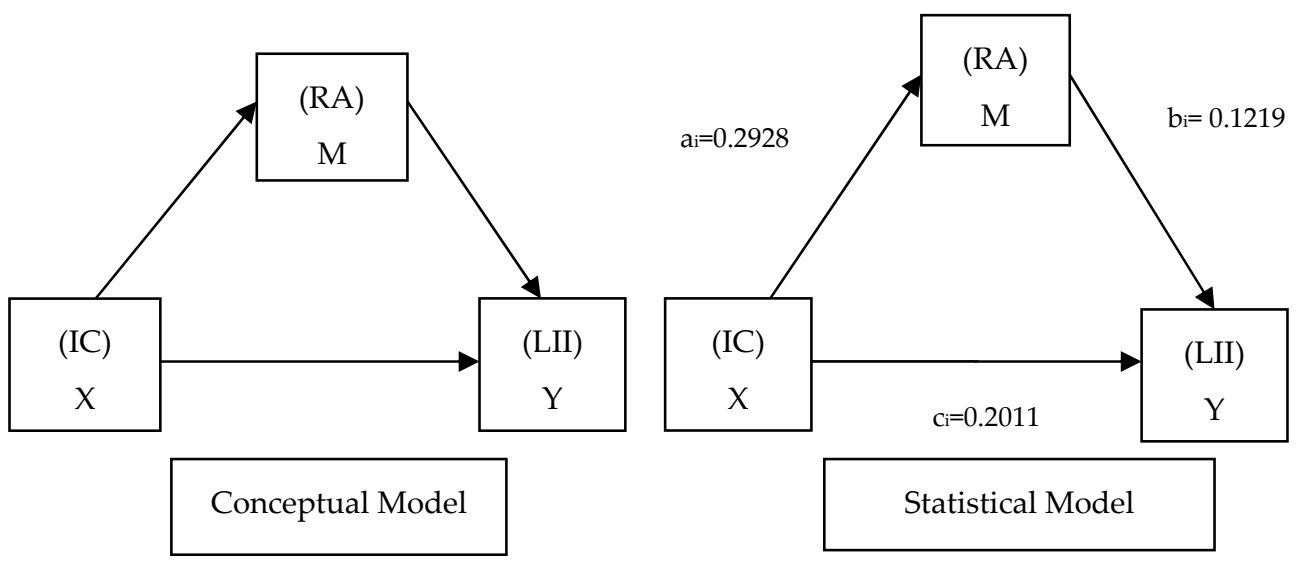

Figure 1. Hayes Statistical Model (Model-4).

Model: 4 Sample Size-392

Y: LII (Level/degree of interest in investment)

$\mathrm{X}$ : IC (Investors' Cognition)

M: RA (Risk Absorption)

The effect of investors' cognition (IC) on the level of interest in investment (LII) mediating through risk-absorption characteristics (RA) has been tested for this research. 
The study is being conducted for testing the direct effect of IC on LII, the direct effect of IC on RA, the direct effect of RA on LII and the indirect effect of IC on LII through RA.

The direct effect of investors' cognition on the risk-absorption behaviour is $29 \%$, as the R-square value is 0.2928 , and this is significant, as the $p$ value is within the range of 0.050 , as shown in Table 9. The path coefficient of model is 0.5411 , and this is significant, as the zero does not fall between LLCI and ULCI, as shown in Table 10.

Table 9. Model Summary.

\begin{tabular}{ccccccc}
\hline \multicolumn{7}{c}{ Outcome Variable: RA } \\
\hline $\mathbf{7}$ & \multicolumn{7}{c}{ Model Summary } \\
\hline $\mathbf{R}$ & R-sq & MSE & F & df1 & df2 & $p$ \\
\hline 0.5411 & $\mathbf{0 . 2 9 2 8}^{*}$ & 0.1418 & 161.4572 & 1.0000 & 390.0000 & $\mathbf{0 . 0 0 0 0}$ * \\
\hline
\end{tabular}

Table 10. Model Values.

\begin{tabular}{ccccccc}
\hline & \multicolumn{7}{c}{ Model } \\
\hline & coeff & se & t & $p$ & LLCI & ULCI \\
\hline constant & 0.0000 & 0.0190 & 0.0000 & 1.0000 & -0.0374 & 0.0374 \\
\hline IC & $\mathbf{0 . 5 4 1 1 *}$ & 0426 & 12.7066 & $\mathbf{0 . 0 0 0 0}$ & 0.4574 & 0.6248 \\
\hline
\end{tabular}

The composite effect of the IC and RA on LII is $41 \%$, as the R square value is 0.4147 and is significant, as shown in Table 11. The individual path coefficient for the portion of modelsis 0.2009 for IC and 0.7312 for RA, which are significant, as the zero values do not fall between LLCI and ULCI, as shown in Table 12.

Table 11. Model Summary.

\begin{tabular}{ccccccc}
\hline \multicolumn{7}{c}{ Outcome Variable: LII } \\
\hline $\mathbf{7}$ & Model Summary \\
\hline $\mathbf{R}$ & R-sq & MSE & F & df1 & df2 & $p$ \\
\hline 0.6439 & $\mathbf{0 . 4 1 4 7 *}$ & 0.2083 & 137.7839 & 2.0000 & 389.0000 & $\mathbf{0 . 0 0 0 0}$ \\
\hline
\end{tabular}

Table 12. Model values.

\begin{tabular}{ccccccc}
\hline & \multicolumn{7}{c}{ Model } \\
\hline & coeff & se & $\mathbf{t}$ & $\boldsymbol{p}$ & LLCI & ULCI \\
\hline constant & 3.7022 & 0.0231 & 160.6113 & $\mathbf{0 . 0 0 0 0}$ & 3.6568 & 3.7475 \\
\hline IC & $\mathbf{0 . 2 0 0 9 *}$ & 0.0614 & 3.2742 & $\mathbf{0 . 0 0 1 2} *$ & 0.0803 & 0.3216 \\
\hline RA & $\mathbf{0 . 7 3 1 2 *}$ & 0.0614 & 11.9142 & $\mathbf{0 . 0 0 0 0} *$ & 0.6105 & 0.8518 \\
\hline
\end{tabular}

The effect of the IC on LII is $20 \%$, as the R square value is 0.2011 and is significant, as shown in Table 13. The individual path coefficient for the portion of model is 0.5966 for IC, which is significant as the zero value does not fall between LLCI and ULCI, as shown in Table 14.

Table 13. Model Summary.

\begin{tabular}{ccccccc}
\hline \multicolumn{7}{c}{ Outcome Variable: LII } \\
\hline Model Summary \\
\hline R & R-sq & MSE & F & df1 & df2 & $p$ \\
\hline 0.4484 & $\mathbf{0 . 2 0 1 1 *}^{*}$ & 0.2836 & 98.1472 & 1.0000 & 390.0000 & $\mathbf{0 . 0 0 0 0 *}$ \\
\hline
\end{tabular}


Table 14. Model Values.

\begin{tabular}{ccccccc}
\hline \multicolumn{7}{c}{ Model } \\
\hline & coeff & se & t & $\boldsymbol{p}$ & LLCI & ULCI \\
\hline constant & 3.7022 & 0.0269 & 137.6518 & $\mathbf{0 . 0 0 0 0} *$ & 3.6493 & 3.7550 \\
\hline IC & $\mathbf{0 . 5 9 6 6 *}^{*}$ & 0.0602 & 9.9069 & $\mathbf{0 . 0 0 0 0} *$ & 0.4782 & 0.7149 \\
\hline
\end{tabular}

3.6. Total Effect of $X$ and $M$ on $Y$, Direct Effect $X$ on $Y$ and Indirect Effect of $X$ on $Y$ through $M$

The total effect IC on LII through the mediator of RA constitutes almost $60 \%$, as the effect shows as 0.5966 , which is significant, as the $\mathrm{P}$ value is less than 0.05 , as shown in Table 15 .

Table 15. Total effect of $X$ on $Y$.

\begin{tabular}{cccccc}
\hline \multicolumn{7}{c}{ Total Effect of X on $\mathbf{Y}$} \\
\hline Effect & se & $\mathbf{t}$ & $\boldsymbol{p}$ & LLCI & ULCI \\
\hline $\mathbf{0 . 5 9 6 6 *}^{*}$ & 0.0602 & 9.9069 & $\mathbf{0 . 0 0 0 0 *}$ & 0.4782 & 0.7149 \\
\hline
\end{tabular}

The direct effect of IC on LII without meditation is $20 \%$, as the effect is 0.2009 , which is significant $(p=0.0012)$, which is within the range of 0.050 , as shown in Table 16 .

Table 16. Direct effect of $X$ on $Y$.

\begin{tabular}{cccccc}
\hline \multicolumn{7}{c}{ Direct Effect of $\mathbf{X}$ on $\mathbf{~}$} \\
\hline Effect & se & $\mathbf{t}$ & $\boldsymbol{p}$ & LLCI & ULCI \\
\hline $\mathbf{0 . 2 0 0 9}^{*}$ & 0.0614 & 3.2742 & $\mathbf{0 . 0 0 1 2} *$ & 0.0803 & 0.3216 \\
\hline
\end{tabular}

The un-standardised indirect effect of the IC on LII is the product of the path coefficient from IC to RA and RA to LII, which is 0.5411 X $0.7312=0.3956$ and the Boot value zero does not fall between LLCI and ULCI, which shows that the path value coefficient is significant, as shown in Table 17.

Table 17. Indirect Effect(s) of X on $Y$.

\begin{tabular}{ccccc}
\hline \multicolumn{5}{c}{ Indirect Effect(s) of X on Y } \\
\hline & Effect & BootSE & BootLLCI & BootULCI \\
\hline RA & $\mathbf{0 . 3 9 5 6}$ & 0.0474 & 0.2999 & 0.4857 \\
\hline \multicolumn{4}{c}{ Level of confidence for all confidence intervals in output: 95.0000 } \\
\hline \multicolumn{4}{l}{ Number of bootstrap samples for percentile bootstrap confidence intervals: 5000} \\
\hline
\end{tabular}

\section{Discussion}

The study focused on investors' psychological behaviour with regard to investment scenarios. It was found from the study that investment decisions are always in a need of information processing abilities along with the intention of taking valuable risks for better return. The study found that the mental processing of information has different dimensions of information processing from various sources. They are hot cognition, cold cognition, social cognition and meta cognition. Along with that, the past investment experience and success leads to better knowledge processing capabilities, which indirectly resulted in better investment strategies. The studies found that the dimension of investors' cognition along with risk-absorption character have a significant impact on the level of interest in investment. The study elaborated different ways of mental processing, which can be used by the financial product marketer to understand and provide relevant information as per 
the investors' mental processing capabilities, so they can form an intent to invest in the domestic capital market through their sense of information processing.

The study also showed the characteristics of investors having risk absorption and found that the investor having risk absorption possesses five characteristics, which are risk seeking attitude, strategic investment planner, recurrence in investment, risk tolerance or tolerance behaviour and protracted or longer duration of investment. The study also found that the risk-absorption nature mediates the relationship of the investors' cognition and level of interest in the investment. The study shows that the mediating impacts of investors' cognition along with risk-absorption characteristics have a greater impact than the direct relationship between the investors' cognition and level of interest in investment. The marketer can classify investors on the basis of risk-absorption capacity and could make strategies, which could motivate them to take a steady and firmed decision. The study can also help the mutual fund companies to formulate strategies to build the risk-absorption capacity through effective advertising and informative strategies.

The study, however, is limited to a state of one developing nation. Further study can be made in this regard in other developing nations to set policies in many countries to face and revive from any anticipated financial crisis.

\subsection{Theoretical Contribution}

Just like India, most of the South Asian countries face unsustainable capital inadequacy, as these countries have significantly failed to understand theirown investors, who are basically risk averse in nature. Clearly, the strategies made to bring about the trust of the investors on the domestic capital market have been futile. The study reflects sources that could change the investment behaviours of the investors, which are basically cognitive in nature. The different dimensions of cognition create different investment perception towards the financial products. The better and more trustworthy is the cognitive elements, the greater the success in developing investment behaviour for a strong investment scenario. The study also took another step in categorising the investor on the basis of risk-taking abilities (previously, risk averse, risk neutral and risk taker). A new term, i.e., "riskabsorbed", has been coined to portray an elite class of investors, those have been using those entire cognitive dimensions for their ultimate investment decision making. These categories of investors are proven to be potential investors.

\subsection{Practical Contribution}

The study will be proven as a helping hand for the asset management companies and financial services providers for strategizing the concepts derived in the study to understandthe domestic investors and encourage them to invest in the domestic market and in the relevant products. The different dimensions can be used to understand the brain mechanism of the investors and can set respective plans to manoeuvre their investor behaviour. The four dimensions can lead to four alternative patterns for providing trustworthy information, which could bring a sense of trust in the minds of the investor, and they could feel secure in the investment. The study can help the strategy makers of different financial service providers to categorise and follow those specific elite groups of risk-absorbed investors with specific characters, as discussed earlier in the study, to draw investment for a longer duration of time. These investments with long duration end in sustainable capital adequacy in an economy.

\subsection{Limitation of the Study}

The study is based on 392 responses. Had it been of more responses, more reliable inferences could have been drawn. This study is based on the Odisha prospective. With a larger geographical base like other states of India as well as other parts of developing countries, a better result could have been extracted. The study focused only on the cognitive part of the investors, ignoring the affective, conative and psychomotor component. The combination of the tri-components can bring a healthy result in this section of study. 


\subsection{Scope for Future Research}

Further research can be done in this field, where different dimensions of cognition can be studied to amplify investment brain mechanism towards investment scenarios. The other components of attitude formation such asthe conative, affective and psychomotor can be studied along with different dimensions of cognitions and can provide better and more reliable results. More focuses could be given to understand other different traits of risk-absorbed investors to categorise them in the elite group. Different other researchers from different developing countries can make collaborative research to come to new and common conclusions for inspiring investor to invest in the domestic economy and market.

\section{Conclusions}

Failure in the past investment and domestic economic crisis because of foreign economic break down has scared the domestic investors away frominvesting in the capital market. For the procurement of steady capital for the financial need of the nation, the participation of the domestic investors is very much necessary. Encouraging domestic investors has been a major necessity for "Atmanirbhar Bharat" (self-reliant India) with regard to capital adequacy from domestic sources. For this purpose, understanding, informing, strengthening and influencing the modern day investors has never been imperative as it has become in this digital era. Therefore, better strategies must be evolved to make people aware and understand all the information relating investment, so that persons with risk-absorption capacity can process that information and can develop good investment strategies and will enhance their level of interest in investment. Strategy makers can use the different dimensions of cognition to become knowledgeableabout the sources of information that investors adhere to and can use those sources for educating and developing investors' sentiments towards investment. Marketers of financial products such assystematic investment plans (SIP) and mutual funds can use the different dimensions of cognition as different sources motivating the investor according to their information processing level and can set strategies accordingly. With the use of technology, it has been very easy to provide information through a different channel, which could build risk-absorption capacity, which can result in a better firmed decision. In the hands of marketers, the study has proven to be of greater importance, as it can use both the dimensions of cognition as well as traits of risk absorption for providing available systematic information to the investors for better understanding of the investment scenario and to take greater risk in investment, which can solve the problem of lack of domestic investment from domestic investors. The strategies also help the nation to procure better, trustworthy and steady sources of capital for economic development and sustainability.

Author Contributions: Conceptualization: Y.D.P.B., S.S.N. and S.K.S.; methodology, S.K.S.; software, Y.D.P.B. (SPSS and Process Macro 3.5v); validation, S.S.N., S.K.S. and T.R.S.; formal analysis, Y.D.P.B. and S.K.S.; investigation, Y.D.P.B., and T.R.S.; resources, Y.D.P.B. and S.S.N.; data curation, S.S.N. and S.K.S.; writing—original draft preparation: Y.D.P.B.; writing—review and editing, S.S.N., S.K.S. and T.R.S.; visualization, Y.D.P.B.; supervision, S.K.S. All authors have read and agreed to the published version of the manuscript.

Funding: The research received no external funding.

Conflicts of Interest: The authors declare no conflict of interest.

\section{References}

Agrawal, Ashish. 2020. Sequoia-Sequoia India's investment in Grow. Available online: https://www.sequoiacap.com/india/article/ sequoia-groww-investment/ (accessed on 15 July 2020).

Akhter, Rahnuma, and Sultan Ahmed. 2013. Behavioral Aspects of Individual Investors for Investment in Bangladesh Stock Market. International Journal of Ethics in Social Sciences 1: 57-70.

Anbar, Adem, and Melek Eker. 2010. An Empirical Investigation for Determining of the Relation between Personal Financial Risk Tolerance and Demographic Characteristics. Ege Academic Review 10: 503-22. [CrossRef] 
Anderson, Travis. 2016. A Quantitative Study on the Relationship between Family Relationship and Financial Education on Financial Risk Tolerance. La Jolla Ranch: Northcentral University.

Aydemir, Sibel Dinc, and Selim Aren. 2017. Do the effects of individual factors on financial risk-taking behavior diversify with financial literacy? Kybernetes 46: 1706-34. [CrossRef]

Bakari, Sayef. 2017. The Impact of Domestic Investment on Economic Growth: New Evidence from Malaysia. MPRA Paper No. 79436. Available online: https:/ / mpra.ub.uni-muenchen.de/id/eprint/79436 (accessed on 7 July 2020).

Bal, Debi Prasad, Devi Prasad Dash, and Bibhudutta Subhasish. 2016. The Effects of Capital Formation on Economic Growth in India: Evidence from ARDL-bound Testing Approach. Global Business Review 17: 11-28. [CrossRef]

Bennet, E., M. Selvam, N. Vivek, and Eva Esther Shalin. 2012. The impact of investors' sentiment on the equity market: Evidence from Indian stock market. African Journal of Business Management 6: 9317-25. [CrossRef]

Bhushan, Puneet. 2014. Insights into awareness level and investment behaviour of salaried individuals towards financial. International Journal of Engineering, Business and Enterprise Applications (IJEBEA) 8: 53-57.

Blackwell, K. C., D. Vaughn Becker, and Greg Adams. 2011. Hot Cognition: Exploring the Relationship Between excessive Call Volume and Cognitive Fatigue. Fire Fighter Health and Safety July, 88-93. [CrossRef]

Bluedorn, John, Gita Gopinath, and Damiano Sandri. 2020. An Early View of the Economic Impact of the Pandemic in 5 Charts. Available online: https://blogs.imf.org/2020/04/06/an-early-view-of-the-economic-impact-of-the-pandemic-in-5-charts / (accessed on 7 July 2020).

Boateng, Henry, and Abednego Feehi Okoe. 2015. Consumers' attitude towards social media advertising and their behavioural response the moderating role of corporate reputation. Journal Research in Interactive Marketing 9: 299-312. [CrossRef]

Bounkhong, Tiffany. 2017. Factors Affecting Intentions to Use Social Commerce in Shopping for Fashion Products. Master's thesis, General Human Environmental Sciences, Tuscaloosa, Alabama.

Broihanne, M. H., M. Merli, and P. Roger. 2014. Overconfidence, risk perception and the risk-taking behaviour of finance professionals. Finance Research Letters 11: 64-73. [CrossRef]

Bruhn, Manfred, Verena Schoenmueller, and Daniela B. Schäfer. 2012. Are social media replacing traditional media in terms of brand equity creation? Management Research Review 35: 770-90. [CrossRef]

Cabosky, Joseph. 2016. Social media opinion sharing: Beyond volume. Journal of Consumer Marketing 33: 172-81. [CrossRef]

Caycedo, Sofia. 2018. Foreign Direct Investment in Developing Countries: A Blessing or a Curse? I Yale Environment Review. Yale Environment Review. Available online: https:/ / environment-review.yale.edu/foreign-direct-investment-developing-countries-blessing-orcurse (accessed on 28 August 2020).

Chattopadhyay, Sandip, and Ranjan Dasgupta. 2015. Demographic and Socioeconomic Impact on Risk Attitudes of the Indian Investors-An Empirical Study. Asian Economic and Financial Review Journal 5: 601-23. [CrossRef]

Cherry, Kendra. 2019. Social Cognition in Psychology. Available online: https:/ / www.verywellmind.com/social-cognition-2795912 (accessed on 20 July 2019).

Cochran, William Gemmell. 1963. Sampling Techniques, 2nd ed. Hoboken: John Wiley and Sons, Inc.

Cocosila, Mihail, and Andy Igonor. 2015. How important is the "social" in social networking? A perceived value empirical investigation. Information Technology E People 28: 366-82. [CrossRef]

Corter, James E., and Yuh jia Chen. 2006. Do Investment Risk Tolerance Attitudes Predict Portfolio Risk? Yuh-JiaChen. Journal of Business and Psychology 20: 369-81. [CrossRef]

Currás-Pérez, Rafael, Carla Ruiz-Mafé, and Silvia Sanz-Blas. 2013. Social network loyalty: Evaluating the role of attitude, perceived risk and satisfaction. Online Information Review 37: 61-82. [CrossRef]

De, Abhishek. 2020. Coronavirus Cases: Check Covid-19 Status in the Top 10 Worst-Affected Nations. The Indian Express. Available online: https:/ /indianexpress.com/article/world/covid-19-a-status-check-of-the-10-worst-hit-countries-6908833/ (accessed on 15 July 2020).

Dev, Op. 2014. Are You Risk-Averse, Risk-Neutral, or Risk-Seeking? Available online: https:/ /binaryoptionsbrokers.ca/risk-takers / (accessed on 20 July 2020).

Dhingra, Rekha, Vidhi Bhargava, Sheetal Chadda, and Rahul Dhingra. 2017. Investor's Behavior Regarding Investment-An Empirical Case Study. Effulgence 15: 39-44. [CrossRef]

Dickason, Zandri, and Sune Ferreira. 2018. Establishing a link between risk tolerance, investor personality and behavioural finance in South Africa. Cogent Economics and Finance 6: 1-13. [CrossRef]

Duffett, Rodney Graeme. 2015. Facebook advertising's influence on intention-to-purchase and purchase amongst millennials. Internet Research 25: 498-526. [CrossRef]

Feldman, Todd, and Gabriele Lepori. 2016. Asset price formation and behavioralbiases. Review of Behavioral Finance 8: 137-55. [CrossRef]

Ferreira, Jorge Brantes, Angilberto Sabino de Freitas, Deborah Coutinho Gil Nunes, and Christiane Junqueira Giovannine. 2014. Factors Affecting Satisfaction in Online Financial Transactions: A study of Brazilian home brokers. Brasileira de Gestão de Negócios-RBGN 16: 257-76. [CrossRef]

Fiske, S. 1993. Social Cognition and Social Perception. Annual Review of Psychology 44: 155-94. [CrossRef]

Grable, Je Erin. 2000. Financial risk tolerance and additional factors that affect risk taking in everyday money matters. Journal of Business and Psychology 14: 625-30. [CrossRef] 
Guo, Hui. 2012. An Empirical Study on the Relation between Meta-cognitive Strategies and Listening Autonomous Learning Ability. Theory and Practice in Language Studies 2: 2446-51. [CrossRef]

Harris, Christopher, and Chen Wu. 2014. Using tri-reference point theory to evaluate risk attitude and the effects of financial incentives in a gamified crowdsourcing task. Journal of Business Economics 84: 281-302. [CrossRef]

Hayes, Andrew. 2013. Introduction to Mediation, Moderation, and Conditional Process Analysis A Regression-Based Approach. Introduction to Mediation, Moderation and Conditional Process Analysis. New York: Guilford Press.

$\mathrm{He}, \mathrm{Wu}$, Jiancheng Shen, Xin Tian, Yaohang Li, Vasudeva Akula, Gongjun Yan, and Ran Tao. 2015. Gaining competitive intelligence from social media data. Industrial Management \& Data Systems 115: 1622-36. [CrossRef]

IBRD. 2017. How Developing Countries Can Get the Most Out of Direct Investment; The World Bank. Available online: https:/ www. worldbank.org/en/topic/competitiveness/publication/global-investment-competitiveness-report (accessed on 24 June 2020).

Ickes, William, Linda Stinson, Victor Bissonnette, and Stella Garcia. 1990. Naturalistic Social Cognition: Empathic Accuracy in Mixed-Sex Dyads. Journal of Personality and Social Psychology 59: 730-42. [CrossRef]

Islamoğlu, Mehmet, Mehmet Apan, and Adem Ayvali. 2015. Determination of Factors Affecting Individual Investor Behaviours: A Study on Bankers. International Journal of Economics and Financial Issues 5: 531-43.

Jagongo, Ambrose, and Vincent Mutswenje. 2014. A Survey of the Factors Influencing Investment Decisions: The Case of Individual Investors at the NSE. International Journal of Humanities and Social Science 4: 92-102.

Kannadhasan, M. 2015. Retail investors' financial risk tolerance and their risk-taking behaviour: The role of demographics as differentiating and classifying factors. IIMB Management Review 27: 175-84. [CrossRef]

Khan, Shamila Nabi. 2017. Financial Risk Tolerance: An Analysis of Investor's Cognitive, Decision-Making Styles and Cultural Effects. Journal of Finance, Accounting and Management 8: 20-38.

Kim, Jinsoo. 2012. The Role of Affect and Cognition in the Impact of Positive/Negative Online Consumer Reviews on Brand Attitude and PurchaseIntention. Gainesville: University of Florida.

Kshetri, Anita, and Bidyanand Jha. 2016. Online Purchase Intention: A Study of Automobile Sector in India. Review of Integrative Business E Economics Research 5: 35-60.

Lakshman, Nikhil. 2011. Economic Effect of Japanese Disaster on India, Globe-Rediff.com Business. Available online: https://www. rediff.com/business/slide-show/slide-show-1-economic-effect-of-japanese-disaster-on-india-globe/20110317.htm (accessed on 7 July 2020).

Lee, Hsiu Ming, Chien Pen Chuang, Jeen Fong Li, and Yu Chun Huang. 2012. A Study on the Relation between Meta-Cognition and Problem Solving Ability among the Students of Mechanical Engineering. Applied Mechanics and Materials 263-66: 3439-43. [CrossRef]

Mane, Priti. 2016. A Study of Investors Perception towards Mutual Funds in the City of Aurangabad. The SIJ Transactions on Industrial, Financial \& Business Management (IFBM) 4: 30-8.

Massa, Massimo. 2003. How do family strategies affect fund performance? When performance-maximization is not the only game in town. Journal of Financial Economics 67: 249-304. [CrossRef]

Merle, Renae. 2018. A guide to the Financial Crisis-10 Years Later. Available online: https:/ /www.washingtonpost.com/business/ economy /a-guide-to-the-financial-crisis--10-years-later/2018/09/10/114b76ba-af10-11e8-a20b-5f4f84429666_story.html (accessed on 3 July 2020).

Mohan, R., and Smriti Singh. 2017. An Empirical Study on Financial Risk Tolerance of Investors in India. The IUP Journal of Financial Risk Management XIV 14: 40-58.

Mukherjee, Subho. 2012. Eurozone Crisis and Its Impact on Indian Economy. Available online: https://www.economicsdiscussion. net/indian-economy/eurozone-crisis-and-its-impact-on-indian-economy/11095 (accessed on 7 July 2020).

Nair, Santosh. 2020. Over 85\% Indian Mutual Fund Investors Come from Top 30 Cities: Report-Moneycontrol.com. Available online: https:/ / www.moneycontrol.com/news/business/markets/over-85-indian-mutual-fund-investors-come-from-top-30 -cities-report-4807861.html (accessed on 15 July 2020).

Niznikiewicz, Margaret A. 2013. Advances in cognitive Psychology the building blocks of social communication. Advances in Cogntive Psychology 9: 173-83. [CrossRef]

Pang, Bo, and Lillian Lee. 2008. Opinion mining and sentiment analysis. Foundations and Trends in Information Retrieval 2: 1-94. [CrossRef]

Peckham, Robert. 2013. Economies of contagion: Financial crisis and pandemic. Economy and Society 42: 226-48. [CrossRef]

Pegkas, Panagiotis, and Constantinos Tsamadias. 2016. How important are foreign and domestic investments, exports and human capital for Greece's economic growth? Economic Issues 21: 23-45.

Pothos, Emmanuel M., and Jerome R. Busemeyer. 2013. Can quantum probability provide a new direction for cognitive modeling? Behavioral and Brain Sciences 36: 255-74. [CrossRef]

Ramakrishnan, Hema. 2020. Indian Economy: Opinion: Impact of covid-19 on the Indian Economy, Government News, ET Government. Available online: https://government.economictimes.indiatimes.com/news/economy/opinion-impact-of-covid-19-on-theindian-economy/75021731 (accessed on 7 July 2020).

Razack, Sarah, and Navitha Thimmaiah. 2014. Impact of Global Financial Crisis on The Indian Economy. International Journal of Business Quantitative Economics and Applied Management Research 1: 105-19. Available online: http://ijbemr.com/wp-content/ uploads/2015/01/Impact-Of-Global-Financial-Crisis-On-The-Indian-Economy1.pdf (accessed on 9 August 2020). 
Reddy, K. Sriharsha, and Mousumi Singha Mahapatra. 2017. Risk tolerance, personal financial knowledge and demographic characteristicsevidence from India. The Journal of Developing Areas 51: 51-62. [CrossRef]

Redlawsk, David P. 2002. Hot Cognition or Cool Consideration? Testing the Effects of Motivated Reasoning on Political Decision Making. The Journal of Politics 64: 1021-1044. Available online: http://www.jstor.org/stable/1520074 (accessed on 20 April 2020).

Sahakian, Barbara. 2017. Hot and Cold Cognition-Serious Science. Available online: http://serious-science.org/hot-and-coldcognition-7976 (accessed on 17 July 2019).

Sahoo, Saroj Kumar, Tushar Ranjan Sahoo, and Biswajit Satpathy. 2020. Virtual Buyer-Seller Interaction Is The True Driver of Online Purchase- Intention: A Study by Ism Approach. Journal of Critical Reviews 7: 651-59. [CrossRef]

Saravana kumar, S., S. Gunasekaran, and R. Aarthy. 2011. Investors Attitude towards Risk and Return Content in Equity and Derivatives. Indian Journal of Commerce E Management Studies 2: 1-11.

Saurabh, Kumar, and Tanuj Nandan. 2018. Role of financial risk attitude and financial behaviour as mediators in financial satisfaction: Empirical evidence from India. South Asian Journal of Business Studies 7: 88-106. [CrossRef]

Shafi, S. M., and Aayat Fatima. 2016. Impact of Demographics on the Investment Behavior of Individual Investors of Kashmir. Global Journal for Research Analysis 5: 14-15. [CrossRef]

Shinde, C. M., and Priyanka Zanvar. 2014. An empirical study on factors influencing in investment decision making in pune. International Research Journal of Management and Commerce 1: 10-23.

Sindhu, K. P., and S. Rajitha Kumar. 2014. Influence of Risk Perception of Investors on Investment Decisions: An Empirical Analysis. Journal of Finance and Bank Management 2: 15-25.

Spencer, John. 2018. Five Ways to Boost Metacognition in the Classrom. Available online: http://www.spencerauthor.com/ metacognition/ (accessed on 21 July 2019).

Srinivas, V. 2011. Major Financial Crisis. Available online: http://nationalarchives.nic.in/sites/default/files/new/Final_Major_ Financial_Crisis-i_0.pdf (accessed on 3 July 2020).

Sukanya, R., and R. Thimmarayappa. 2015. Impact of Behavioural biases in Portfolio Investment Decision Making Process. International Journal of Commerce, Business and Management (IJCBM) 4: 1278-89.

Sultana, Nasrin. 2020. Demat Accounts Gain Currency in FY2020 as Retail Investors Took to Equities. Available online: https://www.livemint.com/news/india/new-demat-accounts-at-record-high-in-fy20-as-retail-investors-took-to-equities-11 588336872289.html (accessed on 15 July 2020).

Sweet, Mollie M. 2013. A Quantitative Study Examining the Relationship between Demographic Factors and Financial Risk Tolerance. San Diego: Northcentral University.

Tidwell, Pamela.S., Cyril J. Sadowski, and Lia M. Pate. 2000. Relationships between Need for Cognition, knowledge and verbal ability. The Journal of Psychology 134: 634-44. [CrossRef] [PubMed]

Wasiuzzaman, Shaista, and Siavash Edalat. 2016. Personality, risk tolerance and social network use: An exploratory study. Managerial Finance 42: 536-552. [CrossRef]

Wengrzyn, Rob. 2013. Types of Attitudes in the Workplace: Cognitive, Affective \&Behavioral Components-Video \& Lesson Transcript I Study.com. Available online: https:/ / study.com/academy/lesson/types-of-attitudes-in-the-workplace-cognitiveaffective-behavioral-components.html (accessed on 20 July 2020).

Wong, Alan, and Bernardo Carducci. 2013. Does Personality Affect Personal Financial Risk Tolerance Behavior? IUP Journal of Applied Finance 19: 5-18.

Yang, Lin. 2015. Empirical study on the relationship between entrepreneurial cognitions and strategic change momentum: The moderating effect of organizational knowledge structures. Management Decision 53: 967-83. [CrossRef]

Yuksel, Mujde, George R. Milne, and Elizabeth G. Miller. 2016. Social media as complementary consumption: The relationship between consumer empowerment and social interactions in experiential and informative contexts. Journal of Consumer Marketing 33: 111-23. [CrossRef] 